\title{
Molecular Systematics of Malpighiaceae: EVIDENCE FROM PLASTID RBCL AND MATK SEQUENCES ${ }^{1}$
}

\author{
Kenneth M. Cameron, ${ }^{2,6}$ Mark W. Chase, ${ }^{3}$ William R. Anderson, ${ }^{4}$ \\ AND HAROLD G. HILlS ${ }^{5}$
}

\begin{abstract}
${ }^{2}$ The Lewis B. and Dorothy Cullman Program for Molecular Systematics Studies, The New York Botanical Garden, Bronx, New York 10458-5126 USA; ${ }^{3}$ Molecular Systematics Section, Jodrell Laboratory, Royal Botanic Gardens, Kew, Richmond, Surrey, TW9 3DS, UK; ${ }^{4}$ University of Michigan Herbarium, North University Building, Ann Arbor, Michigan 48109-1057 USA; and ${ }^{5}$ Molecular Biology Building, Iowa State University, Ames, Iowa 50011-3260 USA
\end{abstract}

\begin{abstract}
Phylogenetic analyses of DNA nucleotide sequences from the plastid genes $r b c L$ and $m a t K$ were employed to investigate intergeneric relationships within Malpighiaceae. Cladistic relationships generated from the independent data matrices for the family are generally in agreement with those from the combined matrix. At the base of Malpighiaceae are several clades mostly representing genera from a paraphyletic subfamily Byrsonimoideae. Intergeneric relationships among these byrsonimoid malpighs are well supported by the bootstrap, and the tribe Galphimeae is monophyletic. There is also a well-supported clade of genera corresponding to tribes Banisterieae plus Gaudichaudieae present in all trees, and many of the relationships among these banisterioid malpighs are well supported by the bootstrap. However, tribes Hiraeae and Tricomarieae (the hiraeoid malpighs) are paraphyletic and largely unresolved. Species of Mascagnia are distributed throughout these hiraeoid clades, confirming the suspected polyphyly of this large genus. Optimization of selected morphological characters on these trees demonstrates clear phylogenetic trends such as the evolution of globally symmetrical from radially symmetrical pollen, increased modification and sterilization of stamens, and switch from base chromosome number $n=$ 6 to $n=10$.
\end{abstract}

Key words: cladistics; DNA; Malpighiaceae; matK; molecular; phylogeny; rbcL; systematics.

Malpighiaceae are a morphologically coherent family of primarily woody, tropical and subtropical dicotyledons composed of $>1250$ species in some 65 genera. They exhibit considerable variability in such features as habit, pollen morphology, leaf vesture, and especially fruit structure. In contrast, the floral morphology of Malpighiaceae is rather conserved (Anderson, 1979). There does exist variation in floral characters (e.g., calyx gland number, size, and distribution), but most species exhibit a stereotyped architecture of five sepals often with paired abaxial glands, five clawed and most commonly yellow petals, ten stamens, and three carpels. Undoubtedly, this general floral structure is strongly influenced by selective pressure from hymenopteran pollinators that, in the Neotropics, visit the flowers to collect oil (Vogel, 1990).

On the one hand, derived features shared by all malpighs easily set the family apart from other rosid families as an undisputedly monophyletic unit. On the other hand, these synapomorphies have made difficult the assessment of sister-group relationships of the family (Cronquist, 1981). This contrast has, likewise, impaired the study of phylogenetic relationships within the family and construction of a satisfactory classification system. As seen in other angiosperm families such as

${ }^{1}$ Manuscript received 10 August 2000; revision accepted 13 February 2001. The authors thank the Royal Botanic Gardens, Kew, the University of Michigan, the University of North Carolina at Chapel Hill, The New York Botanical Garden, the Lewis B. and Dorothy Cullman Foundation, Fairchild Tropical Garden, A. de Bruijn, A. Cox, P. Cuenod, L. Cabrera, and C. Anderson for their assistance in preparing this paper. In addition, the following individuals kindly assisted in collecting plant material: G. Adelson, J. H. Beaman, P. E. Berry, R. Callejas P., M. Cházaro, D. F. Coelho, C. L. Cristóbal, C. C. Davis, R. J. Evans, P. Goldblatt, M. Grayum, W. A. Haber, B. Hammel, G. Hatschbach, E. Knox, A. Krapovickas, M. Lavin, L. S. Leoni, G. D. McPherson, S. A. Mori, A. Schinini, K. E. Steiner, R. Vanni, O. Vargas, and T. A. Zanoni. This project was partially funded by the U.S. National Science Foundation with a DEB grant to MWC and WRA.

${ }^{6}$ Author for correspondence (e-mail: kcameron@ @nybg.org).
Orchidaceae (Dodson, 1962), extreme diversification driven by strong selection from environmental, dispersal, and pollinator pressures has also led to high levels of homoplasy among morphological characters in the malpighs. For these reasons, we believe that nearly every classification of Malpighiaceae has been plagued by recognition of almost certainly para- and/or polyphyletic subfamilies, tribes, subtribes, and even genera (Anderson, 1981).

Table 1 compares four different systems of intrafamilial classification for Malpighiaceae. Niedenzu (1928) divided the family into two subfamilies, Pyramidotorae and Planitorae (corrected to Gaudichaudioideae and Malpighioideae by Morton in 1968), primarily on the basis of winged vs. unwinged fruits. Similarly, fruit characters served as the principal basis for erecting five tribes: Hiraeeae for genera with lateral wings, Banisterieae for those with dorsal wings, Tricomarieae for genera with setiferous fruits, Malpighieae for those with drupaceous fruits, and Galphimieae for genera with other unwinged fruit types. These tribes were further divided into various subtribes. Hutchinson's (1967) system for the family was not dramatically different from Niedenzu's. He recognized no subfamilies, but divided the family into five tribes: Malpighieae for taxa with unwinged, smooth-walled fruits; Tricomarieae for unwinged, setiferous fruits; Hiraeeae for syncarpous taxa with lateral wings; Banisterieae for syncarpous taxa with dorsal wings; and Gaudichaudieae for variously winged, apocarpous taxa with dimorphic flowers.

Recently, Takhtajan (1997) provided an intrafamilial classification for Malpighiaceae in his treatise on flowering plants. His system recognized three subfamilies: Malpighioideae for taxa with unwinged, smooth-walled fruits; Gaudichaudioideae for apocarpous taxa usually with winged fruits and dimorphic flowers; and Hiraeoideae for syncarpous taxa with winged fruits. This last subfamily was further divided into four tribes without stated justification (Table 1). 
TABLE 1. Comparison of select intrafamilial taxonomic treatments for Malpighiaceae.

\begin{tabular}{|c|c|c|c|}
\hline Niedenzu, 1928 (Morton, 1968) & Hutchinson, 1967 & Anderson, 1978 & Takhtajan, 1997 \\
\hline $\begin{array}{l}\text { Subfamily Planitorae (Malpighioideae) } \\
\text { Tribe Malpighieae } \\
\text { Subtribe Malpighiinae } \\
\text { Subtribe Byrsoniminae }\end{array}$ & Tribe Malpighieae & $\begin{array}{l}\text { Subfamily Byrsonimoideae } \\
\text { Tribe Byrsonimeae }\end{array}$ & Subfamily Malpighioideae \\
\hline $\begin{array}{l}\text { Tribe Galphimieae } \\
\text { Subtribe Thryallidinae } \\
\text { Subtribe Galphimiinae }\end{array}$ & & $\begin{array}{l}\text { Tribe Galphimieae } \\
\text { Tribe Acmanthereae }\end{array}$ & \\
\hline $\begin{array}{l}\text { Subfamily Pyramidotorae (Gaudichaudioideae) } \\
\text { Tribe Hiraeeae (Hiptageae) }\end{array}$ & Tribe Gaudichaudieae & Not treated further & $\begin{array}{l}\text { Subfamily Gaudichaudiodeae } \\
\text { Subfamily Hiraeoideae }\end{array}$ \\
\hline $\begin{array}{l}\text { Subtribe Aspidopteryginae } \\
\text { Subtribe Mascagniinae }\end{array}$ & Tribe Hiraeeae & & Tribe Hiraeeae \\
\hline $\begin{array}{l}\text { Tribe Banisterieae } \\
\text { Subtribe Sphedamnocarpinae } \\
\text { Subtribe Banisteriinae }\end{array}$ & Tribe Banisterieae & & $\begin{array}{l}\text { Tribe Banisterieae } \\
\text { Tribe Rhyncophoreae }\end{array}$ \\
\hline Tribe Tricomarieae & Tribe Tricomarieae & & Tribe Tricomarieae \\
\hline
\end{tabular}

Although generally dissatisfied with all three of these systems, Anderson has refrained from proposing a new classification system for the whole family because of too many uncertainties about convergence among the wing-fruited genera. He and collaborators have, however, taken several steps in this direction: first, by producing revisions for individual genera including Acmanthera (Anderson, 1975), Banisteriopsis (Gates, 1982), Callaeum (Johnson, 1986), Dicella (Chase, 1981), Jubelina (Anderson, 1990b), and Stigmaphyllon (Anderson, 1997); and second, by recognizing a new subfamily, Byrsonimoideae, for the American taxa with plesiomorphic, unwinged, smooth-walled fruits (Anderson, 1978). This subfamily generally corresponds to Niedenzu's (1928) subfamily Malpighioideae but does not include the genera Malpighia or Bunchosia, in which fleshy, drupe-like fruits have been shown to be independently derived (Anderson, 1978).

The study presented here is an attempt to employ plastid DNA sequences of nearly all genera in Malpighiaceae to address intrafamilial relationships. We have chosen to sequence the gene $r b c L$ because of its proven utility in reconstructing phylogenetic relationships at the family level (Cameron et al., 1999; Chase, Morton, and Kallunki, 1999; Lledó et al., 1998). In addition, we have chosen to sequence the $\operatorname{mat} K$ gene for a complementary set of taxa. This gene has been shown to have as many as three times more variable sites than $r b c L$ (Johnson and Soltis, 1994) and also to be appropriate for family-level phylogenetic reconstruction (Plunkett, Soltis, and Soltis, 1996; Steele and Vilgalys, 1994; Johnson and Soltis, 1994). Davis, Anderson, and Donoghue (2001) have studied the same group of taxa for two additional plastid loci, $n d h F$ and $t r n L-F$. It is hoped that ultimately by combining all of these molecular data sets, a clearer picture of intrafamilial relationships will result. This can then be used to guide further studies on taxonomy, biogeography, character evolution, and reproductive biology in Malpighiaceae.

\section{MATERIALS AND METHODS}

Table 2 lists the four outgroup and 74 ingroup species used in this analysis. Of the 65 currently recognized genera in Malpighiaceae, we sampled at least one species from each genus, with the following exceptions: Camarea, Clonodia, Diplopterys, Excentradenia, Henleophytum, Digoniopterys, Philgamia, Microsteira, and Brachylophon. Most taxa were collected in the field, pre- served in silica gel (Chase and Hills, 1991), and vouchered as herbarium specimens. In some instances, DNA was extracted from herbarium material. Total DNA was extracted according to the procedures outlined in Palmer et al. (1988) with the hot 2X CTAB method of Doyle and Doyle (1987) being most often employed. All extractions were purified on ethidium bromide/CsCl gradients $(1.55 \mathrm{~g} / \mathrm{mL})$ and stored at $-80^{\circ} \mathrm{C}$.

rbch sequencing-More than half of these $r b c L$ sequences were completed by manually sequencing purified, double-stranded PCR products according to the procedure outlined in Chase et al. (1993). Most recently, however, sequences were produced by automated methods on a PE Applied Biosystems 377A sequencer (ABI, Warrington, Cheshire, UK) in the Jodrell Laboratory at the Royal Botanic Gardens, Kew, according to the manufacturer's protocols. This method involves standard gene amplification by the polymerase chain reaction (PCR) and purification of amplified products using QIAquick silica columns (Qiagen, Crawley, West Sussex, UK), followed by cycle sequencing reactions directly on the PCR products in a thermal cycler. After 35 cycles, the reactions were cleaned of unincorporated dyes with Centri-Sep (Princeton Separations, Inc., Adelphia, New Jersey, USA) columns, dried, and stored at $-20^{\circ} \mathrm{C}$. The stored samples were rehydrated with a mixture of deionized formamide and loading dye, denatured by heating, and loaded on an acrylamide gel. Overnight runs of $\sim 7 \mathrm{~h}$ resulted in computer-analyzed electropherograms, which were edited using a combination of computer software including Sequence Navigator and Autoassembler (PE Applied Biosystems). Each base position was examined for congruence of complementary strands.

Regardless of the method used, templates were amplified with primers that correspond to the highly conserved, first 20 base pairs (bp) of the $r b c L$ coding sequence and to a 23-bp region downstream from the $r b c L$ exon (Lledó et al., 1998). The $r b c L$ matrix thus consists of sequences that are nearly complete except for the first $20 \mathrm{bp}$, at which position the forward PCR primer annealed. Four or five internal primers were usually sufficient to determine the nearly complete gene sequence with adequate overlap of primers to ensure accuracy.

matK sequencing-To develop a sequencing strategy with primers specific to Malpighiaceae, $\sim 2500 \mathrm{bp}$ of sequence within the $\operatorname{trn\mathrm {K}}$ intron (including the matK gene) were initially amplified from Triopterys rigida and Hiptage benghalensis. Amplification of this region was achieved using the trnK-3914F and $t r n \mathrm{~K}-2 \mathrm{R}$ primers (Johnson and Soltis, 1994). Subsequent manual sequencing of direct PCR product was attempted using each of the internal matK primers listed by Johnson and Soltis (1994). Of these, only the matK-934F, $m a t K-1168 \mathrm{R}$, mat $K-1412 \mathrm{~F}$, and $m a t K-1506 \mathrm{R}$ produced quality sequence. This sampling resulted in adequate coverage and quantity of both forward and reverse strands to design additional primers specific to Malpighiaceae for amplification and sequencing. These included primers matK-1135F 
(TTCCTTTGATTGGATCAT), mat $K$-400F (CCCTAATTTACGATCAATTCATTCAAT), $m a t K$-842F (GATCCTTTCATACATTATGT), mat $K$-1390R (TGGAAGAATTTTTTACGGAGGA), and $m a t K-1 \mathrm{~F}$ (TCAAATTGAAAATTCAA), which flanks the $5^{\prime}$ end of the $m a t K$ gene and became the forward PCR primer of choice. As with $r b c L$, the majority of sequences were produced by manual methods, but the automated sequencing method described above was employed most recently. Many of the $m a t K$ sequences were complete for the whole reading frame, and no internal stop codons were detected. Length variation was present, and the aligned matrix has gaps included to mark these insertions and deletions, which always occurred in triplets. No matK sequence was obtained for 12 ingroup species, and only a partial mat $K$ sequence $(\sim 50 \%)$ was completed for nine species. We completed an $r b c L$ sequence for all but one species (Table 2).

Data analysis—Phylogenetic analyses were conducted using the parsimony algorithm of the software package PAUP* (Phylogenetic Analysis Using Parsimony, version 4.0b2: Swofford, 1999). For $r b c L$, missing data at the $5^{\prime}$ end were excluded such that only base pair positions 30-1428 were used; these were easily aligned by eye as there were no insertions or deletions detected. For $m a t K$, all positions from base pair 1-1596 were used. Short insertions and deletions ranging from 3 to $15 \mathrm{bp}$ (in threes) were encountered among the taxa; these were easily aligned within the matK matrix, and the reading frame appeared to be maintained.

On the basis of larger phylogenetic analyses (Chase et al., 1993; Savolainen et al., 2000a, b; Soltis et al., 2000), taxa from the allied rosid families Passifloraceae and Saxifragaceae were used as outgroups. Peridiscaceae (Whittonia) were also discovered to be closely related based on a large $r b c L$ analysis of eudicots (Savolainen et al., 2000b), and we use it here as an additional outgroup. However, due to the poor quality of the DNA extracted from an herbarium specimen, only $r b c L$ could be amplified. Shortest trees were initially found using the routine outlined by Olmstead and Palmer (1994): heuristic searches of 1000 random taxon-addition replicates under the Fitch criterion (unordered with equal weights; Fitch, 1971) were executed with tree bisection and reconstruction (TBR) swapping and MulTrees in effect, but keeping only two trees for each replicate to reduce time spent in swapping on suboptimal trees. The resulting trees were then used as starting trees to find as many trees of maximum parsimony (MulTrees option in effect) as possible. Branches were collapsed if minimum length $=0$, and gaps in the mat $K$ sequences were treated as missing data. The existence of islands of equally most parsimonious trees was evaluated by using one of the most parsimonious trees found as a starting tree. If this search produced a strict consensus tree identical to that found with the trees from the random replicates, this would be an indication that all tree were from a single island (which was the case here, so this topic will not be considered further).

Bootstrap analysis (1000 replicates, full heuristic search using simple addition sequence and TBR branch swapping) was applied to each matrix as an evaluation of internal support. All clades discovered in at least $50 \%$ of these replicates are reported. We assessed congruence of the separate data sets by visual inspection of the individual bootstrap consensus trees. We considered the bootstrap trees to be incongruent only if they displayed "hard" (i.e., high bootstrap support) incongruence, rather than "soft" (i.e., low or no bootstrap support) incongruence (Seelanan, Schnabel, and Wendel, 1997; Wiens, 1998).

Results that differ without strong bootstrap support are likely the result of sampling error (i.e., too few taxa and/or variable sites to obtain a clear result), particularly for two plastid DNA regions that must have the same pattern of inheritance. To discuss trends in pollen evolution, character states were traced on a molecular tree using MacClade (Maddison and Maddison, 1992). To calculate the number of transitions and transversions (and their consistency indexes [CIs] and retention indexes [RIs]) observed on one of the shortest combined data trees, we used a stepmatrix to calculate the number of transversions at each base position by weighting the transitions to zero. After invoking the "Typesets" command in PAUP* and loading one of the shortest trees, the "Tree score" command was used to calculate the number of transversions and their collective CI and RI (ACCTRAN optimization). From these, we calculated values for transitions.

\section{RESULTS}

rbcL data-For the $r b c L$ matrix, 337 (24\%) of the 1398 characters are variable, and $180(13 \%)$ are potentially parsimony informative from the 77 included taxa. A total of 663 equally parsimonious trees were found. These trees have a length of 754 steps, CI of 0.53 , and RI of 0.67 . The strict consensus of these 663 trees is presented as Fig. 1 along with bootstrap percentages. Twenty-six clades receive bootstrap support of $50 \%$ or greater. Of these, 13 receive $75 \%$ or greater. There is little support along the spine of the tree and generally poor resolution of intergeneric relationships in the strict consensus.

In these $r b c L$ trees, the Old World genus Acridocarpus is sister to all Malpighiaceae, followed by two clades composed of taxa representing subfamily Byrsonimoideae and the enigmatic genus Barnebya. Although there is strong support for some tribal relationships within these "byrsonimoid clades" (e.g., Galphimieae, $80 \%$ ), the subfamily is not monophyletic. Genera representing Hutchinson's tribe Gaudichaudieae are monophyletic and well supported (76\%). These morphologically derived taxa are members of a larger, monophyletic clade that also includes most genera of tribe Banisterieae. Together we refer to these lineages as the "banisterioid clades." Aspicarpa (three species sampled) and Gaudichaudia (two species sampled) are polyphyletic and paraphyletic, respectively. Represented by three species, Stigmaphyllon is monophyletic. The four species of Janusia are unresolved, and the genus may not be monophyletic. The remaining Malpighiaceae are mostly unresolved. They include genera from the polyphyletic tribes Tricomarieae and Hiraeeae and are here referred to as the "hiraeoid clades." Among these taxa are several species of Mascagnia, which could be polyphyletic. The most unexpected result seen in the $r b c L$ topology is the placement of Pterandra and Acmanthera among these hiraeoid branches. Morphologically, they should be related to the byrsonimoid malpighs, and this is where $m a t K$ and the combined analyses place them (see below). However, there is no bootstrap support $>50 \%$ for their position in the $r b c L$ tree.

The transition/transversion (ts/tv) ratio for $r b c L$ is similar to those reported in other studies, 1.3; transitions, which are more numerous, have both higher $\mathrm{CI}$ and RI than transversions, 0.61 and 0.68 vs. 0.51 and 0.56 , respectively (Table 3 ). Also, as previously reported in $r b c L$ studies, most of the change is at third positions $(68.0 \%)$ and least at second positions (10.6\%). First positions have the lowest CI and RI (0.48 and 0.55), whereas the far more numerous third-position changes perform much better ( 0.58 and 0.65 ; Table 4$)$.

matK data-Within the matK data matrix, $722(45 \%)$ of the 1596 characters are variable and $410(26 \%)$ are potentially parsimony informative. A total of 140 equally parsimonious trees were found. The have a length of 1348 steps, CI of 0.71, and RI of 0.77 . The strict consensus of these 140 trees is presented (Fig. 2) with bootstrap percentages indicated. Thirtysix clades receive bootstrap support of $50 \%$ or greater. Of these, 21 receive $75 \%$ or greater.

For the most part, analysis of $m a t K$ yields a tree topology that is similar to that of $r b c L$. At the base of the tree are genera representing a paraphyletic Byrsonimoideae including Acridocarpus and Barnebya, followed by a generally unresolved grade of hiraeoid clades. Also recovered is a well-supported (100\%), monophyletic Gaudichaudieae and a paraphyletic 


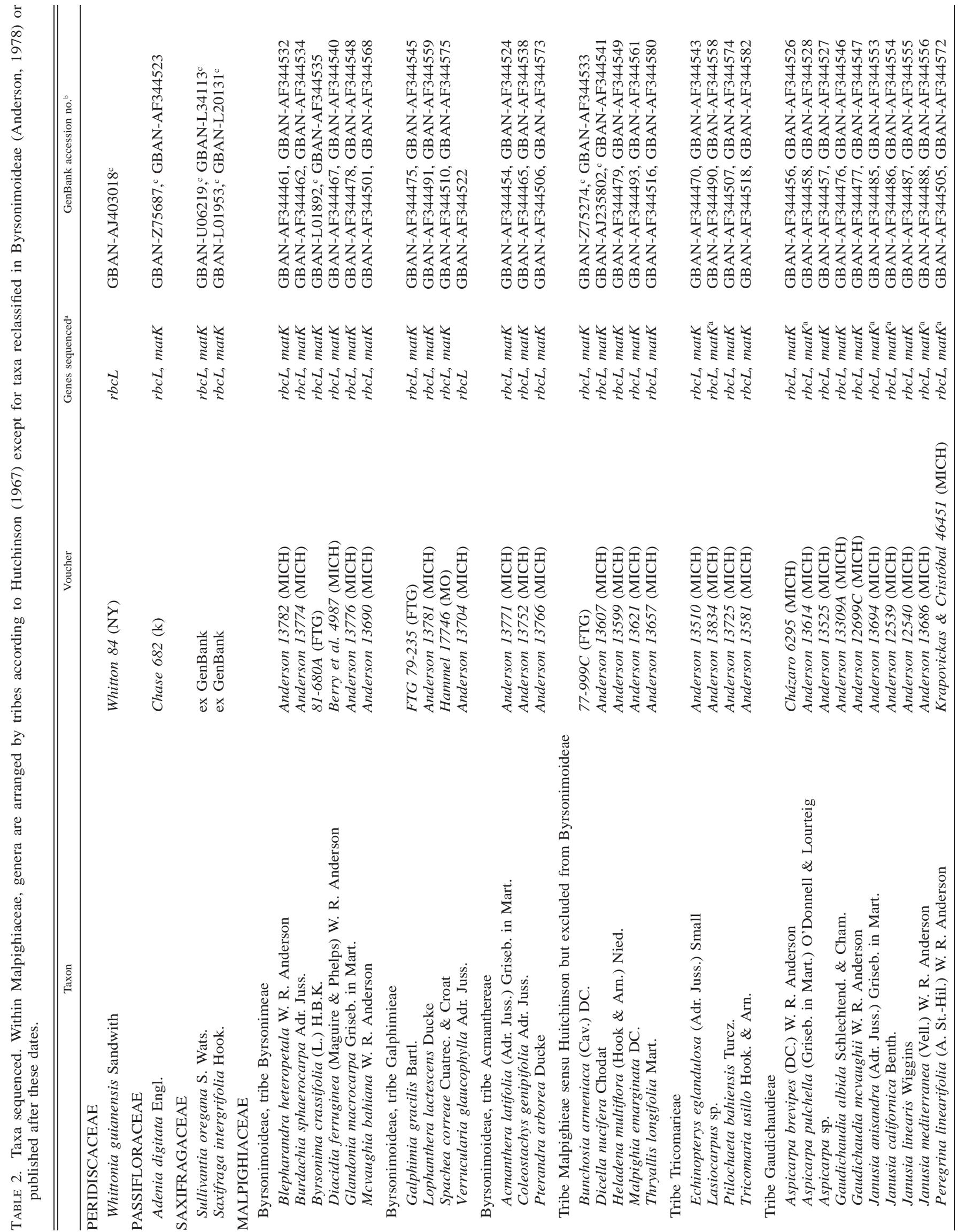




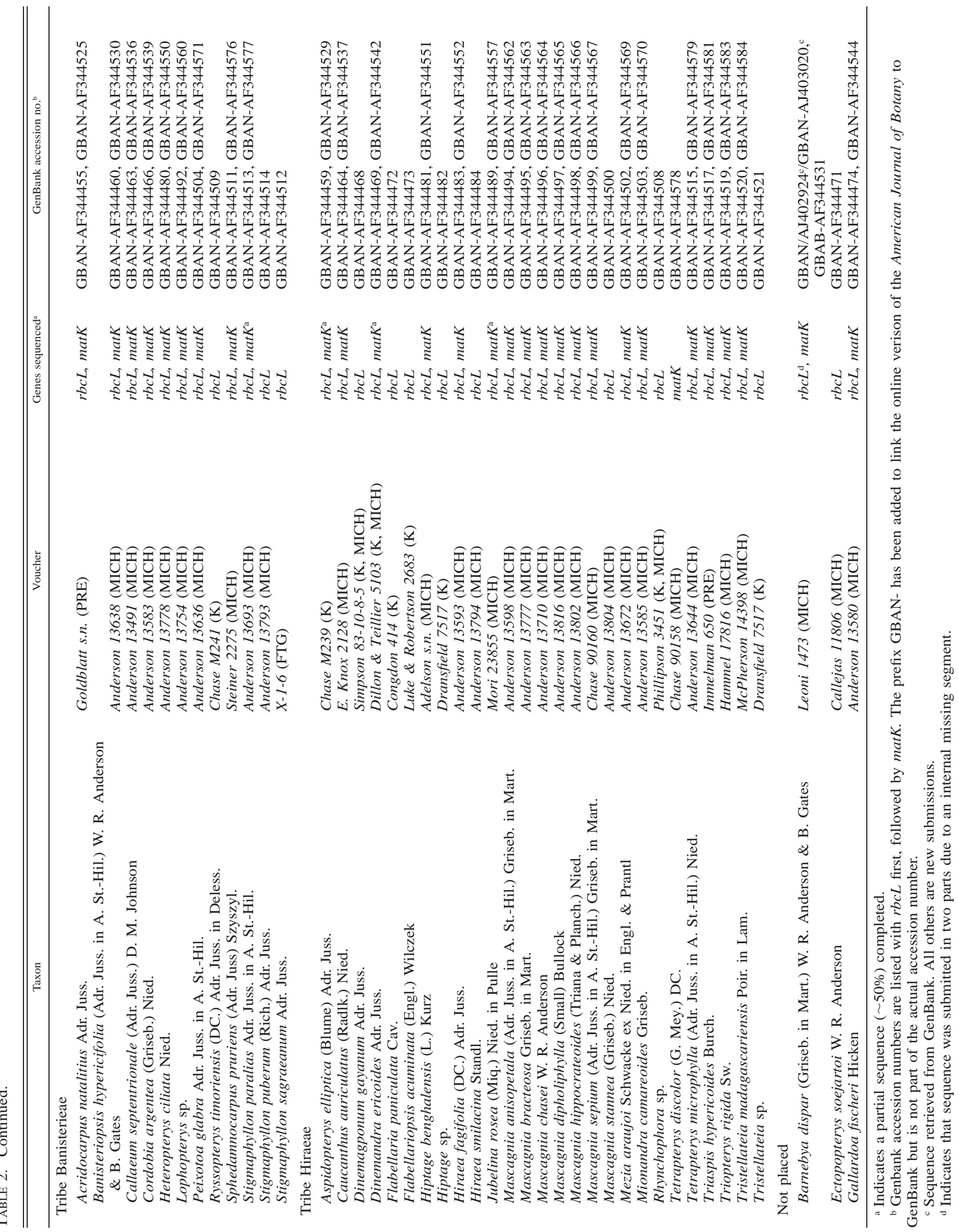




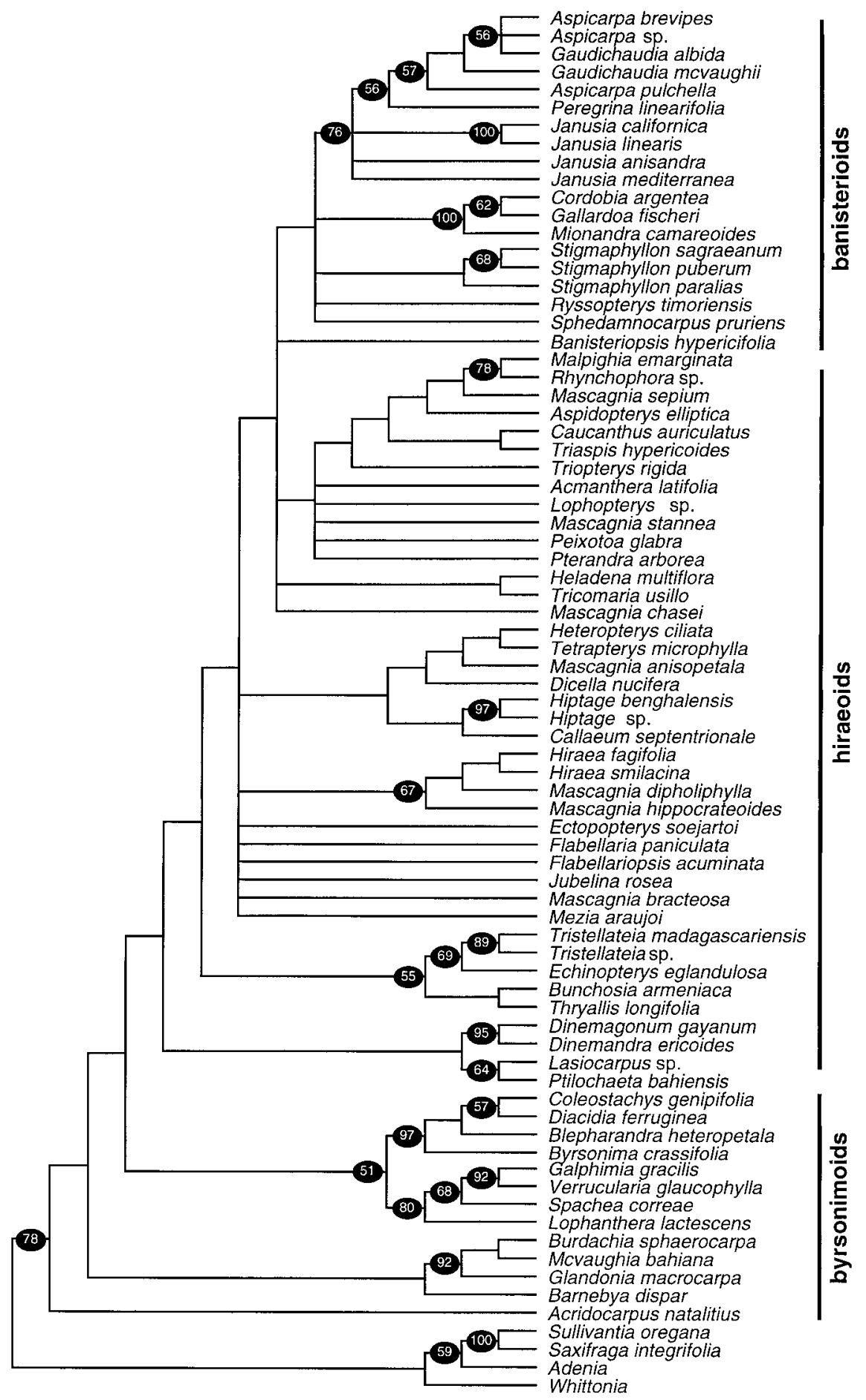

Fig. 1. Strict consensus of 633 equally most-parsimonious trees of Malpighiaceae from analysis of $r b c L$ sequence data. The trees have a consistency index (CI) of 0.53 , retention index (RI) of 0.67 , and length of 754 steps. Clades receiving $50 \%$ or greater bootstrap support are indicated with a solid oval and corresponding percentage.

Banisterieae (together forming a monophyletic banisterioid clade). These matK trees differ from the $r b c L$ trees most strikingly in the increased CI, increased overall resolution, and in the pronounced increase in number of bootstrap-supported clades. Moreover, a considerable amount of support occurs along the spine of the tree, rather than being confined to terminal branches. It is worth noting that matK, unlike $r b c L$, places Pterandra and Acmanthera as sisters to each other with Coleostachys sister to them (i.e., tribe Acmanthereae) among the byrsonimoid clades. As seen in the $r b c L$ topology, Aspicarpa, Janusia, Gaudichaudia, and Mascagnia are not monophyletic.

The ts/tv ratio for $m a t K$ is lower than that for $r b c L, 1.1$; transitions, which are slightly more frequent, have both higher 
TABLE 3. Number of steps, consistency index (CI), and retention index (RI) for transitions and transversion for $r b c L$ and matK based on one of the equally most-parsimonious trees produced using combined data for taxa with complete sequences only. ts/tv $=$ transition/transversion ratio.

\begin{tabular}{lccccc}
\hline \hline & \multicolumn{2}{c}{$r b c L$} & & \multicolumn{2}{c}{ matK } \\
\cline { 2 - 3 } \cline { 5 - 6 } & Transitions & Transversions & & Transitions & Transversions \\
\hline No. of steps & $372(56 \%)$ & $288(44 \%)$ & & $682(53 \%)$ & $604(47 \%)$ \\
CI & 0.61 & 0.51 & & 0.75 & 0.67 \\
RI & 0.68 & 0.56 & & 0.79 & 0.72 \\
ts/tv & \multicolumn{2}{c}{1.3} & & & 1.1 \\
\hline
\end{tabular}

CI and RI than transversions, 0.75 and 0.79 vs. 0.67 and 0.72 , respectively (Table 3 ). Unlike $r b c L$ studies, much less change occurs at third positions $(42.0 \%)$ vs. first and second positions at 30.2 and $26.0 \%$, respectively. The CIs for all positions are nearly the same, but the RI for first positions is the best $(0.80$ vs. 0.67 and 0.72 for firsts and seconds, repectively; Table 4).

Combined data-No hard incongruence was evident between the $r b c L$ and matK trees, so we proceeded with combining these data. For the combined $r b c L$ and/or matK data matrix of all 78 taxa, 288 trees of maximum parsimony were found. In this case, trees have a length of 2155 steps, CI of 0.63 , and RI of 0.71 . To show branch lengths (ACCTRAN optimization), tree number 1 of the 288 is presented (Fig. 3) along with bootstrap percentages. Forty-one clades receive $50 \%$ or greater bootstrap support. Of these, 22 receive $75 \%$ or greater.

As with the individual data matrices, we found no support for the monophyly of Byrsonimoideae. Successive sisters to the rest of Malpighiaceae are two clades of byrsonimoid taxa, followed by a grade of hiraeoid taxa, and a monophyletic banisterioid clade. This strict consensus topology is somewhat more resolved than either the independent $r b c L$ or matK trees, but adding the $r b c L$ data to the matK matrix lowers the level of bootstrap support along the spine of the tree. Nevertheless, these trees confirm that Aspicarpa, Janusia, Stigmaphyllon, and Mascagnia are polyphyletic as currently circumscribed.

To evaluate the effect of missing data on these results, a fourth matrix was constructed that included only those 53 taxa for which complete $r b c L$ and $\operatorname{mat} K$ sequences were available. In this case, $1003(34 \%)$ of the 2994 characters are variable and $553(18 \%)$ of these are potentially parsimony informative. This analysis yielded only 40 trees of 1941 steps with a CI of 0.66 and RI of 0.71 . These trees are well resolved with the exception of a few hiraeoid clades and are characterized by high bootstrap support throughout ( 28 clades at $\geq 50 \%$ and 19 clades at $\geq 75 \%$ ). Tree number 1 of the 40 equally parsimonious trees is illustrated (Fig. 4) along with branch lengths (ACCTRAN optimization), bootstrap percentages, and an indication of clades collapsing in the strict consensus tree (arrowheads). Bootstrap percentages along the spine of this tree are high, indicating the likelihood that the missing data in the combined analysis of all taxa significantly decreased resolution and bootstrap percentages.

A comparison of character and tree statistics for all four data matrices is presented as Table 5. Except for minor differences (all with $<50 \%$ bootstrap support), all four data matrices produced similar topologies. The trees derived from combined data for taxa with complete sequences (Fig. 4) are the most robust estimate of phylogeny for the family presented
TABLE 4. Number of steps, CI, and RI for first, second, and third codon positions in $r b c L$ and $m a t K$ based on one of the equally mostparsimonious trees produced using combined data for taxa with complete sequences only.

\begin{tabular}{lcrcc}
\hline \hline Gene & $\begin{array}{c}\text { Codon } \\
\text { position }\end{array}$ & $\begin{array}{c}\text { No. of steps } \\
\text { (\% of total) }\end{array}$ & CI & RI \\
\hline rbcL & 1 & $141(21.4 \%)$ & 0.48 & 0.55 \\
& 2 & $70(10.6 \%)$ & 0.56 & 0.59 \\
\multirow{3}{*}{ matK } & 3 & $449(68.0 \%)$ & 0.58 & 0.65 \\
& 1 & $388(30.2 \%)$ & 0.73 & 0.80 \\
& 2 & $339(26.4 \%)$ & 0.74 & 0.67 \\
& 3 & $559(43.5 \%)$ & 0.76 & 0.72 \\
\hline
\end{tabular}

in this paper. However, these trees are missing several taxa that are critical for discussing intrafamilial relationships and evolution in Malpighiaceae. For this reason, we will refer to the combined $r b c L$ and/or $m a t K$ consensus tree for all taxa (Fig. 3) in the discussion.

\section{DISCUSSION}

Molecular evolution-Several studies of both dicot and monocot taxa have shown that $\operatorname{mat} K$ may be a pseudogene (Johnson and Soltis, 1994; Steele and Vilgalys, 1994; Xiang, Soltis, and Soltis, 1998; Kores et al., 2000; Whitten, Williams, and Chase, 2000). The sequence data generated for Orchidaceae by Whitten, Williams, and Chase (2000) particularly support the potential pseudogene status of matK in that they showed a $66 \%$ excess of transversions over transitions and only a slight excess of substitutions at third codon positions. The matK data presented here for Malpighiaceae show a similar pattern. The ts/tv ratio for these data is 1.1 , which is low in comparison to 1.6 and 1.8 uncovered in the large angiosperm data sets for $r b c L$ and $a t p B$ (Savolainen et al., 2000a) and the $r b c L$ data presented here for Malpighiaceae (Table 3). More striking is the relatively even distribution of substitutions across codon postions for matK (30-26-44\%) when compared to $r b c L$ (21-11-68\%) for the taxa presented here (Table 4). These same trends were reported by Steele and Vilgalys (1994) for a variety of taxon pairs and by Xiang, Soltis, and Soltis (1998) for Cornaceae.

The strict consensus trees from the separate analyses of $r b c L$ and $m a t K$ contain some patterns that appear to be strikingly different and thus potentially incongruent (e.g., those of $A c$ manthera and Pterandra; Figs. 2, 3), and these deserve further consideration and comment. It would be easy to conclude these differences must be evidence of fundamental and true incongruence, and thus these two gene matrices should not be directly combined. Two lines of evidence indicate that this is in fact not the case. The first is the complete lack of bootstrap support for their respective placements in the $r b c L$ trees; not a single clade between their alternative positions in the $r b c L$ vs. the $m a t K /$ combined analyses has bootstrap support $>50 \%$. This indicates to us that the positions of Acmanthera and Pterandra in the $r b c L$ tree could be due to simple sampling error. Secondly, if their $r b c L$ placement reflects true incongruence, then we would expect a decrease in the bootstrap percentages for the clades in between in the combined analysis, but we find no such decrease. Their clade in the matK analysis received 95\% (Fig. 2), whereas in the combined analysis (Fig. 4 ), the same clade also received $95 \%$. In our opinion, there is simply a lack of signal in the $r b c L$ trees for the placement of some genera, and this sampling error effect should not be tak- 


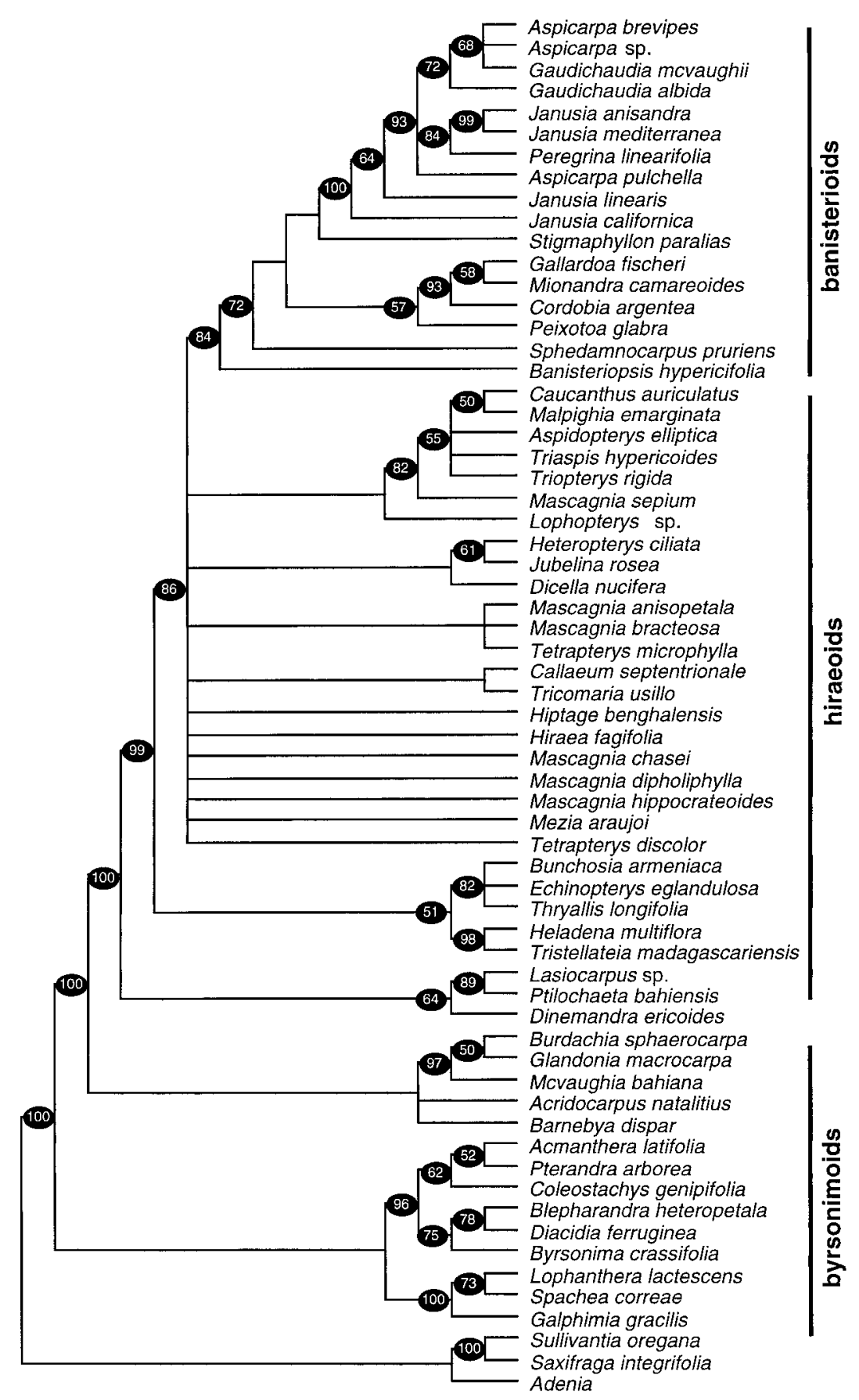

Fig. 2. Strict consensus of 140 equally most-parsimonious trees of Malpighiaceae from analysis of $m a t K$ sequence data. The trees have a CI of 0.72 , an RI of 0.77 , and a length of 1348 steps. Clades receiving $50 \%$ or greater bootstrap support are indicated with a solid oval and corresponding percentage. Note the increased number of supported clades compared to the $r b c L$ tree and especially the higher level of bootstrap support along the spine of the tree.

en as a reason for not directly combining these data. A similar pattern was observed in Iridaceae for certain genera sequenced for plastid $r b c L, r p s 4$ and $t r n L-F$ (Reeves et al., in press).

These data, like those of several other studies (Olmstead, Reeves, and Yen, 1998; Chase et al., 2000; Reeves et al., in press), demonstrate that frequency of change for various categories of substitutions and performance (as indicated by the RI) are not correlated. Characters that change too frequently are often down-weighted or eliminated from analyses without an examination of how well they perform. We use here the retention index as a measure of performance; RI is a measure of how well patterns of change fit the inferred topology. For $r b c L$, performance and frequency are positively correlated (i.e., substitution categories that experience more frequent change have higher RIs), whereas for matK that pattern is more mixed (Tables 3 and 4). Thus weighting schemes that assign weights based on frequency of change would not achieve the desired effect of down-weighting the less informative substitutions.

The combined analysis with and without the taxa for which 


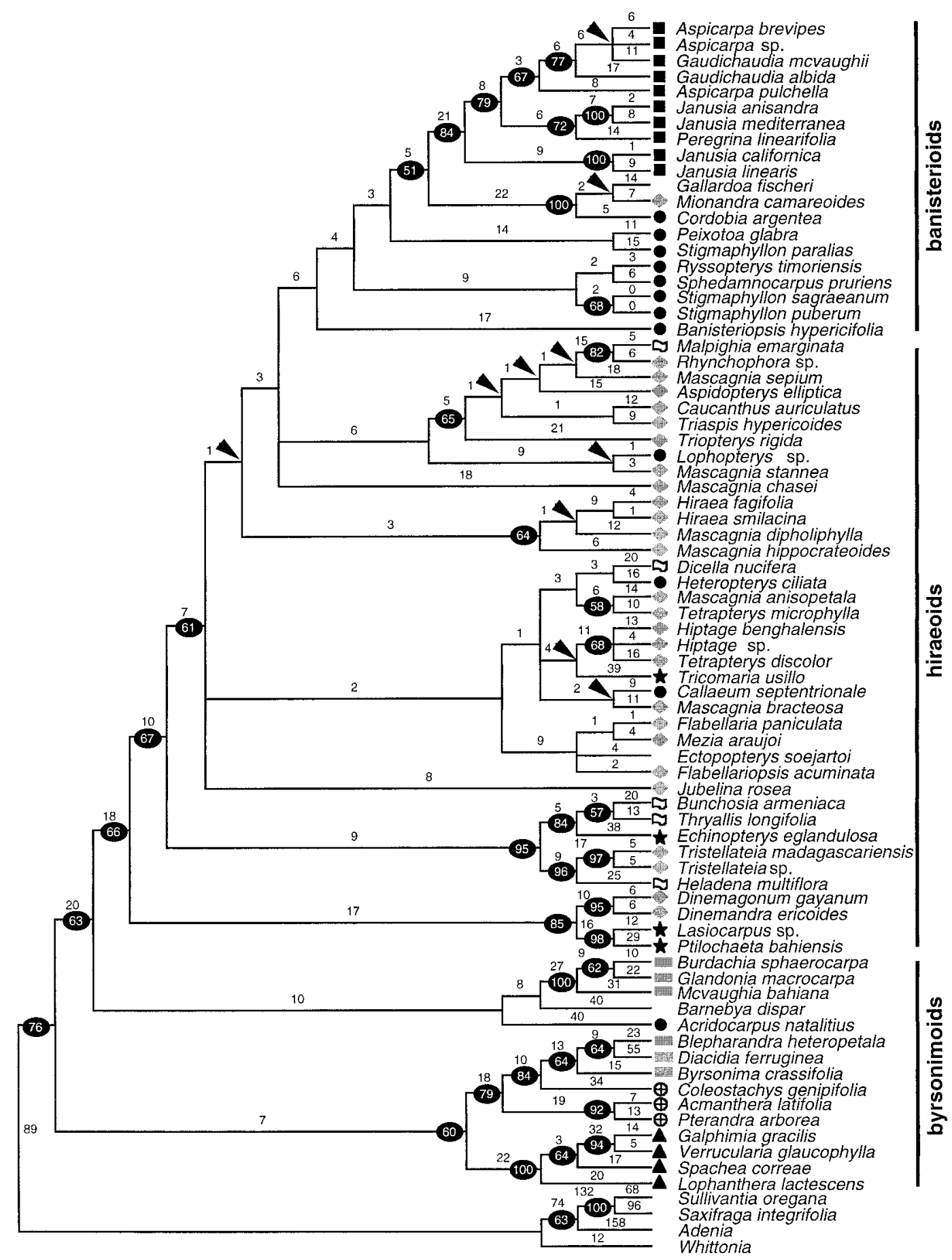

Fig. 3. One of 288 equally most-parsimonious trees of Malpighiaceae from analysis of combined $r b c L$ and $m a t K$ sequence data for all taxa, including those with incomplete sequences. The trees have a CI of 0.63 , an RI of 0.71 , and a length of 2155 steps. Branch lengths are indicated above branches, and those clades collapsing in the strict consensus are indicated by arrow heads. Clades receiving $50 \%$ or greater bootstrap support are indicated with a solid oval and corresponding percentage. Symbols correspond to tribes sensu Hutchinson (1967), except for taxa reclassified in Byrsonimoideae (Anderson, 1978) or published after these dates, as follows: $\square=$ Byrsonimoideae, tribe Byrsonimeae; $\boldsymbol{\Delta}=$ Byrsonimoideae, tribe Galphimieae; $\oplus=$ Byrsonimoideae, tribe Acmanthereae; $\mathbf{D}=$ Malpighieae sensu Hutchinson but excluded from Byrsonimoideae; $\star=$ Tricomarieae; $\mathbf{\square}=$ Gaudichaudieae; $\bullet=$ Banisterieae; $\downarrow=$ Hiraeae

data are missing illustrates that although tree topologies are largely unaffected when large amounts of information are absent, bootstrap percentages exhibit a significant decrease. There are more trees when the taxa with missing data are included, but this might be expected to be an effect of missing data. The consistency of pattern is an encouraging result, but we believe that it is important to explore results of bootstrapping and other methods of estimating internal support for taxa with missing data removed, although if $75 \%$ or more cells are present the effect is not noticeable. It is possible that other 


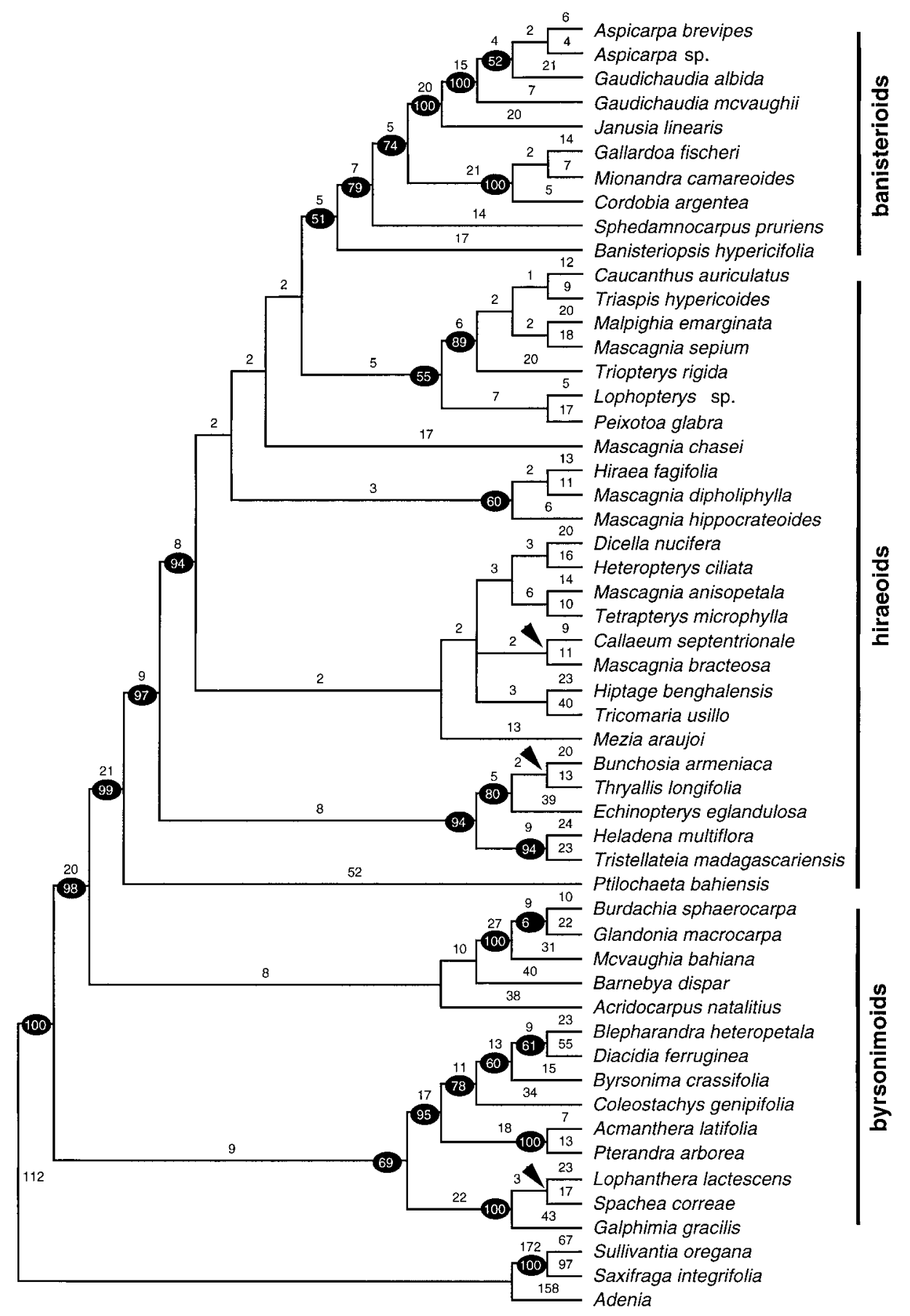

Fig. 4. One of 40 equally most-parsimonious trees of Malpighiaceae from analysis of combined $r b c L$ and $m a t K$ sequence data for taxa with complete sequences for both genes. The trees have a CI of 0.66, an RI of 0.71, and a length of 1941 steps. Branch lengths are indicated above branches, and those few clades that collapse in the strict consensus are indicated by arrowheads. Clades receiving 50\% or greater bootstrap support are indicated with a solid oval and corresponding percentage. Note the higher bootstrap percentages along the spine of the combined analysis when taxa with a large amount of missing data were excluded.

factors could be involved in the decrease of bootstrap percentages when all taxa were included, but the increases observed when these taxa were excluded implicates the missing data as the primary cause.

Systematic implications-According to recent cladistic studies employing multiple molecular data sets, Malpighiaceae are part of a larger clade of eurosid I families recently named Malpighiales (APG, 1998). Other families within this order include Violaceae, Passifloraceae, Linaceae, Clusiaceae, Peridiscaceae, and Euphorbiaceae (Chase et al., 1993; Savolainen et al., 2000a, b; Soltis et al., 2000). These particular interfamilial relationships were somewhat unexpected since Malpighiaceae have most often been allied with families in Po- 
TABLE 5. Comparison of results from $r b c L$, matK, and combined data matrices for Malpighiaceae.

\begin{tabular}{|c|c|c|c|c|}
\hline & $r b c L$ & matK & $\begin{array}{l}r b c L \text { and/or } m a t K \\
\text { for all taxa }\end{array}$ & $\begin{array}{l}r b c L \text { and } m a t K \text { for } \\
\text { taxa with complete } \\
\text { sequences }\end{array}$ \\
\hline Number of taxa included & 77 & 64 & 78 & 53 \\
\hline Total characters included & 1398 & 1596 & 2994 & 2994 \\
\hline Variable characters (\% of total) & $337(24 \%)$ & $722(45 \%)$ & $1059(35 \%)$ & $1003(34 \%)$ \\
\hline $\begin{array}{l}\text { Potentially informative characters } \\
\text { (\% of variable, } \% \text { of total) }\end{array}$ & $180(53 \%, 13 \%)$ & $410(57 \%, 26 \%)$ & $590(56 \%, 20 \%)$ & $553(55 \%, 18 \%)$ \\
\hline No. of equally parsimonious trees & 633 & 140 & 288 & 40 \\
\hline Tree length & 754 & 1348 & 2155 & 1941 \\
\hline CI & 0.53 & 0.71 & 0.63 & 0.66 \\
\hline RI & 0.67 & 0.77 & 0.71 & 0.71 \\
\hline $\begin{array}{l}\text { Proportion of clades supported by bootstrap/number of taxa } \\
(\geq 50 \%, \geq 75 \%)\end{array}$ & $0.34,0.17$ & $0.56,0.33$ & $0.53,0.28$ & $0.53,0.36$ \\
\hline
\end{tabular}

lygalales, but these relationships have been recovered consistently (Chase et al., 1993; Savolainen et al., 2000a, b; Soltis et al., 2000) and are well supported (Soltis et al., 2000). One of the features that is commonly used to distinguish malpighs in the field is the presence of unicellular, T-shaped trichomes. This character is restricted to only a handful of families other than Malpighiaceae, Euphorbiaceae among them in Malpighiales. Both families are also well known for the common presence of extrafloral nectaries, and Lobreau-Callen (1983) commented that the pollen morphology of Malpighiaceae approaches Euphorbiaceae more than any other family. It is also worth comparing Malpighiaceae, which are well known for attracting pollinators with oil, to genera of Euphorbiaceae (Dalechampia) and Clusiaceae (Clusia), which are well known for producing water-insoluble floral resins to attract pollinators (Armbruster, 1984). Peridiscaceae are a small, poorly studied family of two monotypic genera endemic to tropical South America. They are trees with alternate, entire leaves, flowers in small racemes, and drupaceous, one-seeded fruits. The flowers themselves are apetalous with imbricate sepals, numerous stamens, and 3-4 united carpels. Like most byrsonimoid malpighs, Peridiscaceae have intrapetiolar stipules (Cronquist, 1981).

Although Malpighiaceae are clearly related to the other families currently assigned to Malpighiales (Soltis et al., 2000), the exact interfamilial relationships within this order still remain largely uncertain. The shortest trees of Soltis et al. (2000) indicated that the sister taxon of Malpighiaceae is Clusiaceae, but notably with bootstrap percentage $<50 \%$. Peridiscaceae were absent from the Soltis et al. (2000) trees, so this hypothesis could not be evaluated. The problem would appear to be related to the short branches at the base of the order, which make it difficult to estimate relationships; a rapid radiation of lineages $\sim 100$ million years ago (mya) is one explanation for this problem (this date is based on an indisputedly Clusiaceae fossil from 90 mya; Crepet and Nixon, 1998).

As for intrafamilial classification, the molecular trees presented here do not provide convincing evidence that Malpighiaceae can be satisfactorily divided into a small number of monophyletic subfamilies or tribes based on obvious morphological synapomorphies. There is a natural split between the base chromosome $n=6$ clade of ten genera (Lophanthera, Spachea, Verrucularia, Galphimia, Pterandra, Acmanthera, Coleostachys, Byrsonima, Diacidia, and Blepharandra) and the remaining $n=10$ clade (Anderson, 1993), but this character is of no utility to field botanists and hardly appropriate on its own to separate subfamilies, in our opinion. It seems that we must be content for the time being to discuss phylogenetic relationships within Malpighiaceae in terms of informal "byrsonimoid," "hiraeoid," and "banisterioid" assemblages, each composed of several well-supported clades. Only the banisterioid group is clearly monophyletic in our trees. These are essentially the same results obtained by Davis, Anderson, and Donoghue (2001).

Byrsonimoid clades-Sister to the majority of Malpighiaceae is a clade of genera from the paraphyletic subfamily Byrsonimoideae, and sister to all of these is a second clade of byrsonimoid genera. In most cases the intergeneric relationships of these taxa conform to traditional concepts of classification. The tribe Galphimieae (Galphimia, Verrucularia, Lophanthera, and Spachea) is monophyletic; Acmanthera and Pterandra, two of three genera in the family with winged anther loculi, are sisters; and although the indehiscent-fruited tribe Byrsonimeae is polyphyletic, it splits into two small clades, of which one is characterized by the presence of foliar glands (Burdachia and Glandonia) and the other is eglandular (Byrsonima, Diacidia, and Blepharandra).

When Anderson (1978) erected Byrsonimoideae, he excluded Malpighia, Bunchosia, Dicella, Thryallis, Heladena, and Clonodia (not sampled here) from that subfamily. These genera had traditionally been allied to Byrsonima and relatives because of their unwinged fruits, but Anderson provided convincing evidence that these fruit types represent examples of convergence and were likely derived from winged types. Indeed, the molecular data place these excluded genera (except Clonodia, for which we were not able to obtain DNA) outside the byrsonimoid clades, nested within the branches of the hiraeoid malpighs.

Two genera not previously classified within Byrsonimoideae, Acridocarpus and Barnebya, are positioned within one clade of byrsonimoid taxa according to the molecular trees. Classification of these two genera has always been problematic. Both are characterized by a suite of features presumed to be ancestral in Malpighiaceae: tree/shrub habit, subulate styles, radially symmetrical pollen, and racemes of several-flowered cincinni in Barnebya. At the other extreme, these genera have winged mericarps and alternate phyllotaxy (an unusual character in the family); Acridocarpus is found entirely in the Old World, whereas Barnebya is known only from Brazil. Furthermore, Barnebya has a haploid chromosome number of 30 (potentially derived from either $n=6$ or $n=10$ ), perigynous flowers, and pollen without ectoapertures. Both genera are chimeras of primitive and advanced characters. It is interesting to 
note that Barnebya dispar, originally classified as a species of Byrsonima on the basis of floral morphology, was transferred to Banisteria (= Banisteriopsis) on the basis of its fruits. As Anderson and Gates (1981) pointed out, Banisteria "is about as different from Byrsonima as a genus can be and still belong in the Malpighiaceae." When Anderson and Gates described Barnebya, they argued that it was related to Acridocarpus and postulated that these genera served as a link between primitive Byrsonimoideae and the remainder of Malpighiaceae. The clade to which Barnebya and Acridocarpus belong includes Mcvaughia, which is also somewhat anomalous in Byrsonimoideae because it has a chromosome number of $n=10$ rather than $n=6,12$, or 24 . Further investigation into the caryology, fruit morphology, biogeography, and morphological intermediacy of this clade is warranted.

Hiraeoid clades-Generally unresolved and paraphyletic are some 30 genera mostly representing Niedenzu's (1928) and Hutchinson's (1967) concept of Hiraeeae. This tribe is defined primarily by the presence of lateral, as opposed to dorsal, fruit wings. Since resolution and bootstrap support are generally weak among these clades, it is difficult to discuss intergeneric relationships in any detail; however, a few alliances stand out as worthy of attention. One is the weakly supported (57\%) coupling of the two American genera Bunchosia and Thryallis. Bunchosia is a genus of trees and shrubs with fleshy birddispersed fruits, whereas Thryallis is a genus of woody vines with small, nutlike, tardily dehiscent schizocarps, the mericarps neither winged nor fleshy (Anderson, 1995). Thryallis is notable for having stellate hairs (which have evolved only twice in the family, here and in a species complex in Byrsonima), and for its complete lack of calyx glands. Bunchosia is a much more standard malpigh, with typical hairs and calyx glands. They have quite different pollen types (Lowrie, 1982). Indeed, the only obvious morphological links between the two genera are stipules borne on the inner face of the base of the petiole and somewhat similarly shaped terminal stigmas. Those two genera have always been problematic, but we are perplexed by this association.

Another strongly supported (96\%) but surprising pair is Neotropical Heladena and Palaeotropical Tristellateia. Heladena has several species in South America with schizocarpic fruits that break apart into smooth, dry, unwinged cocci. It has stalked calyx glands, but neither its other morphological characters nor our molecular data support a common ancestry with the other clade in which such glands have evolved (i.e., $D i$ nemandra/Dinemagonum). Its stipules, stigmas, and pollen (Lowrie, 1982) all resemble those of Bunchosia, and we would not have been surprised to see them associated. Indeed, both genera do fall out here in a related clade, but clearly not as sisters. Tristellateia has most of its diversity in Madagascar, but at least one species extends across the Asian tropics to Taiwan and the Philippines (Niedenzu, 1928). Its fruit is schizocarpic, with the mericarps bearing well developed, dissected, lateral wings; in that sense it is at home among the hiraeoids, but its fruit bears essentially no resemblance to that of Heladena. Its stipules are borne on the edge of the petiole base, not on the inner face. Its stigmas are long-decurrent on the inner face of the styles, whereas those of Heladena are terminal. Its anthers have apical poricidal dehiscence; those of Heladena are longitudinally dehiscent, as is usual in the family. The only obvious similarity between the genera is the fact that in both the pollen is without ectoapertures, but Lowrie (1982) empha- sized other differences between these two and did not class them in the same pollen "type." The morphological similarities between Heladena and Tristellateia are few indeed, and if the molecular data are telling us the truth in this case, then there has clearly been a great deal of morphological evolution since their divergence.

The close sister relationship between Dinemandra and Dinemagonum, on the other hand, was not unexpected. Both of these genera are characterized by the presence of nearly unique stipitate calyx glands, and they are the only malpighs found in the deserts of Chile. A relationship of this pair to Ptilochaeta and Lasiocarpus would not be predicted on the basis of their fruit morphology, but these four genera all share a similar, derived type of pollen (symmetrically polycolporate), on which basis Lowrie (1982) asserted their mutual affinity.

Heteropterys, which is one of the two largest genera in the family, is consistently embedded deep within the hiraeoid genera. Previous authors (e.g., Niedenzu, 1928) have associated Heteropterys with the banisterioid genera because its samara has a dorsal wing, instead of the lateral wings of most hiraeoids, but it has never fit well among the banisterioids. Its dorsal wing bends the "wrong" way (hence the name, meaning "different wing"), it lacks the cartilaginous carpophore connecting the samara to the receptacle in most banisterioids, and its styles are stigmatic on the internal angle, not over the apex as in most banisterioids. Hiraeoid samaras have a small dorsal crest, and the samaras of Heteropterys sometimes have small lateral crests. Its peculiar samara probably evolved quite independently of the banisterioids, by suppression of the lateral wings and enlargement of the dorsal crest in an ancestor with a hiraeoid samara.

Ectopopterys is a peculiar genus with a samara that is superficially similar to that of Heteropterys and a chromosome number $(n=8)$ unique in the family (Anderson, 1980). When he described the genus, Anderson argued that the apparently dorsal wing of the samara is actually a displaced lateral wing and suggested that this genus is more likely to be related to genera with lateral-winged samaras than to Heteropterys. However, he could not place the genus satisfactorily. The molecular data confirm a hiraeoid affinity for Ectopopterys but shed little further light on its closest relatives.

In several publications over the years, e.g., 1990c, Anderson has suggested that Malpighia was more or less directly derived from Mascagnia sect. Mascagnia by the loss of lateral wings from the samaras and their replacement by a fleshy exocarp. Our sole representative of sect. Mascagnia is M. sepium, and the close association of Mascagnia sepium and Malpighia emarginata in our trees accords with Anderson's morphological argument. The interpolation of Rhynchophora between them is a surprise. Rhynchophora is an enigmatic and poorly known endemic from Madagascar, whereas Malpighia and Mascagnia are Neotropical genera. The fruits of Rhyncophora are composed of three-winged mericarps, but the individual samaras are united to form a presumably indehiscent (or perhaps breaking apart only after maturity), beaked fruit with reflexed wings (Hutchinson, 1967). Regardless of whether dehiscence in Rhyncophora is absent or simply delayed, this could be the type of developmental anomaly that one might envision as necessary to evolve a fleshy, indehiscent fruit from one that is dehiscent and winged. Anderson feels, however, that the strong support for the link between Malpighia and Rhynchophora in our trees should be viewed with caution at 
this point in time and confirmed with additional sequences as soon as possible.

Variously nested among these hiraeoid taxa are genera (Tricomaria, Echinopterys, Lasiocarpus, Ptilochaeta) recognized as Tricomarieae in nearly all previous classifications (Table 1). Ptilochaeta and Lasiocarpus are strongly supported sister taxa, but Tricomarieae are polyphyletic. The setiferous fruits that were used to define the tribe appear to have evolved independently on several occasions.

Before leaving the hiraeoid clades, attention must be given to the large genus Mascagnia, which Niedenzu (1928) split into two subgenera. The first, Mesogynixa, was composed of section Eumascagnia (including subsection Psilopetalis with series Actinandra and Zygandra, and subsection Sericopetalis) and section Pleuropterys. The second subgenus, Plagiogynixa, was not further subdivided. Given Niedenzu's intricate classification scheme, one might have expected that Mascagnia would have been well understood systematically, but nothing could be further from the truth. As it currently stands, Mascagnia has $\sim 50$ species distributed from Mexico to Argentina. They are primarily woody vines producing pseudoracemes of yellow, pink, or blue flowers and fruits with lateral wings. Anderson (1990b) was not embarrassed to admit that "Mascagnia has always been an excessively diverse, certainly paraphyletic and possibly polyphyletic assemblage. Plants currently called Mascagnia share little except plesiomorphic character-states, and . . . a cladist would argue that Mascagnia should be disassembled, with the pieces reattached to the taxa derived from it." We have sampled seven species of Mascagnia for this molecular study, and although resolution and bootstrap support are poor, the evidence is quite strong that the genus is grossly polyphyletic. Further investigations with less conserved DNA regions and far greater sampling of species will be needed to determine how Mascagnia should be split into monophyletic units.

Banisterioid clades-The remaining genera of Malpighiaceae in these trees are members of a paraphyletic tribe Banisterieae and a monophyletic tribe Gaudichaudieae. Together, these banisterioid taxa have always been considered the most morphologically advanced in the family (Anderson, 1990a), and their monophyly has never been questioned. Among these taxa there is a clear trend toward the evolution of derived character states such as the perennial herbaceous habit (found in Aspicarpa, Peregrina, and Mionandra), increased ploidy from a number based on ten $(\mathrm{n}=20,40,80$, or 120 in species of Janusia, Aspicarpa, and Gaudichaudia), anther sterilization from the plesiomorphic state of ten (six, five, three, or as few as two fertile stamens in some species of Stigmaphyllon, Mionandra, Gaudichaudia, and Aspicarpa), stamen heterogeneity, and inflorescence reduction.

Within Gaudichaudieae, Janusia, Peregrina, Aspicarpa, and most species of Gaudichaudia share a reduction in stamen number (five or six) and an apocarpous gynoecium characterized by a single style on the anterior carpel. Some species of both Aspicarpa and Gaudichaudia produce dimorphic flowers (chasmogamous and cleistogamous), as do some Janusia species. There is strong bootstrap support indicating that neither Aspicarpa nor Janusia is monophyletic. In the case of Aspicarpa, two North American species (A. brevipes and A. sp.) are sisters, but $A$. pulchella from South America is a distant outlier with Gaudichaudia falling closer to the former. A similar scenario occurs in Janusia; two North American species
(J. californica and J. linearis) are sisters, two South American species ( $J$. anisandra and $J$. mediterranea) are sisters, but the two pairs are more closely related to species in other genera. Further sampling is needed within these genera, however, before any reclassification is initiated.

Paraphyletic to Gaudichaudieae are taxa mostly classified in tribe Banisterieae. Mionandra has been allied to Hiraeeae by Hutchinson (1967), but its herbaceous habit and androecium of five fertile plus five sterile stamens justifies a position among the banisterioid clades. The inclusion of Stigmaphyllon in this clade is also not terribly surprising, because its samara, including a carpophore, is identical to that of Banisteriopsis. However, it is interesting because its stigmas are on the internal angle of the style apex in most species, just as they are in most hiraeoid genera and quite unlike the terminal, usually capitate stigmas found in most banisterioid genera, including Banisteriopsis. Anderson has long wondered if Stigmaphyllon might have retained its internal stigmas from a hiraeoid ancestor, but the structure of our trees suggests a secondary, de novo origin of those stigmas in Stigmaphyllon, a striking homoplasy. Our combined data trees indicate that Stigmaphyllon may be polyphyletic, but whereas $S$. paralias is hardly typical of the genus, its leaves, inflorescence, androecium, and styles share significant synapomorphies with the rest of Stigmaphyllon, and this is one result of the analysis that we view with skepticism; it is probably an effect of missing data (we have matK for only one species; $r b c L$ places all three in one clade; Fig. 1).

Finally, Banisteriopsis (the modern name for the genus long known as Banisteria) is sister to all the banisterioids, just as morphology would have predicted. It has all the character states one could want in an ancestor for this group: a full complement of fertile stamens, three styles, and a base chromosome number of $n=10$, plus the terminal capitate stigmas, dorsal-winged samaras, and cartilaginous carpophores that seem to be synapomorphies holding together most of these genera. Some, but not all, species of Banisteriopsis have the peculiar type of cuboidal pollen that Lowrie (1982) called banisterioid, which is common in more derived genera in this clade such as Stigmaphyllon, Peixotoa, Aspicarpa, and Gaudichaudia.

Old World genera-Historical biogeography of Malpighiaceae has been debated heatedly (Anderson, 1990a; Vogel, 1990). Seventy-three percent of malpigh genera are restricted to the Neotropics. Two genera, Heteropterys and Stigmaphyllon, are exclusively Neotropical with the exception of a single species in each genus that is thought to have arrived in western Africa by recent dispersal (Anderson, 1990a). Vogel (1990) has postulated that the majority of Old World taxa (in which calyx glands secrete nectar) are ancient relicts of a once-widespread distribution and that the family had evolved prior to the breakup of Gondwana. Anderson (1990a) has countered this hypothesis with his own, in which the family is thought to have originated in the Neotropics. Ancestors of the Old World genera would have dispersed to the Paleotropics after the breakup of Gondwana. The scattered phylogenetic positions of the Old World genera depicted in Fig. 5 favor Anderson's theory that these taxa are the result of several (at least seven) independent dispersal events.

The recent discovery of a 90 million-year-old, clearly recognizable, fossil taxon of Clusiaceae (Crepet and Nixon, 1998), on the other hand, favors the evolution of Malpighi- 


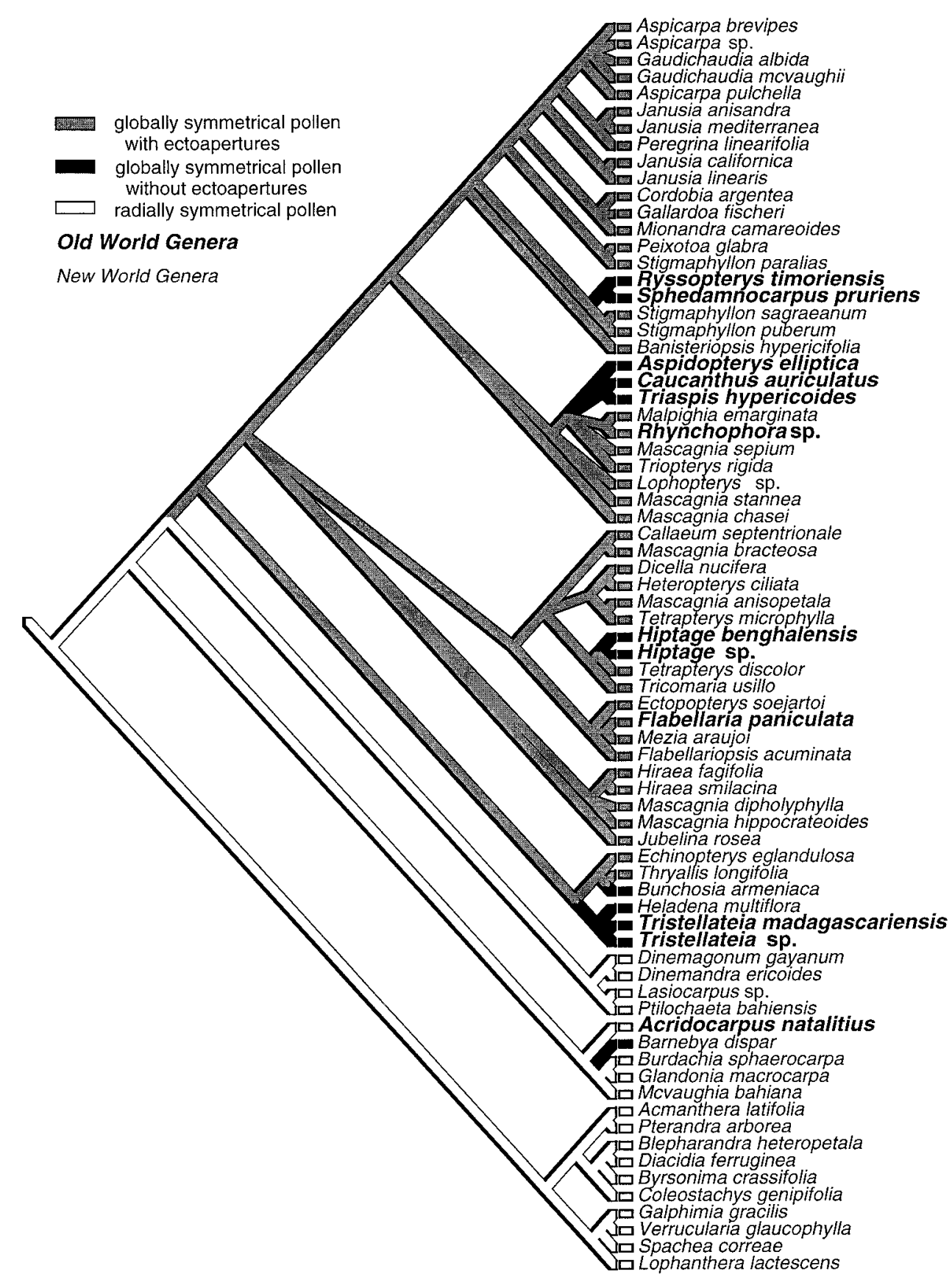

Fig. 5. Geographic distribution and trends in the evolution of pollen types within Malpighiaceae. The strict consensus tree for the ingroup is based on combined $r b c L$ and $m a t K$ data for all taxa (Fig. 3). Taxa restricted to the Old World are indicated by large, bold type. Radially and globally symmetrical pollen types and presence of ectoapertures were optimized onto the tree using MacClade. Note the correlation between Old World distribution and presence of globally symmetrical pollen without ectoapertures.

aceae prior to the breakup of Gondwana given that the ancestor of the lineage leading to these two families would have to be at least this old (or much older since this fossil represents only a minimum age). Although these two families are sister taxa in the three-gene tree for the angiosperms (Soltis et al., 2000), this scenario does not depend on the exact relationship of Clusiaceae and Malpighiaceae, but rather that they both must have shared a common ancestor that was at least this old, thus indicating that Malpighiaceae are likely to have evolved at a similar time. Certainly the higher Hymenoptera that would be needed to pollinate flowers like those of Malpighiaceae were present at such a date (Crepet, 1996). The question of whether malpighs originated in the Old or New World may be moot since it is likely that they existed before either region had a separate geological history. Furthermore, such an age for the family supports the idea that all current distributions have little bearing on the ancestral distribution because they are the results of more recent extinctions and/or radiations. It should be noted that Anderson rejects the argument elaborated in this paragraph. 
The distribution of taxa with globally symmetrical pollen lacking ectoapertures (data derived from Lowrie, 1982) appears to be associated with Old World distribution (Fig. 5). It may be that ectoapertures provide a selective advantage for pollen tube germination to those exclusively New World taxa that produce oils. Pollen generally requires hydration for pollen tube growth, and oils that clog pollen colpi or pores might interfere with this process. However, pollen and oil are carried on different parts of the bee and are not likely to mix, so this theory is purely speculative. Other than this unusual example of parallelism, there is a relatively clear split between taxa with radially symmetrical and globally symmetrical pollen in the family.

Some of the trends in evolution discussed above have been recognized previously (Lowrie, 1982; Anderson, 1990a; Vogel, 1990), but have never been presented in an unbiased phylogenetic context. It is our hope that the results of this study and their interpretation will stimulate future research within Malpighiaceae, a family that has been overlooked as a candidate for evaluating scenarios of evolution and plant-animal interactions.

\section{LITERATURE CITED}

ANDERSON, C. 1995. Revision of Thryallis (Malpighiaceae). Contributions from the University of Michigan Herbarium 20: 3-14.

Anderson, C. 1997. Monograph of Stigmaphyllon (Malpighiaceae). Systematic Botany Monographs 51: 1-313.

Anderson, W. R. 1975. The taxonomy of Acmanthera (Malpighiaceae). Contributions from the University of Michigan Herbarium 11: 41-50.

ANDERSON, W. R. 1978 [“1977”]. Byrsonimoideae, a new subfamily of the Malpighiaceae. Leandra 7: 5-18.

ANDERson, W. R. 1979. Floral conservatism in neotropical Malpighiaceae. Biotropica 11: 219-223.

ANDERSON, W. R. 1980. Ectopopterys, a new genus of Malpighiaceae from Colombia and Peru. Contributions from the University of Michigan Herbarium 14: 11-15.

Anderson, W. R. 1981. Malpighiaceae, in The Botany of the Guayana Highlands-part XI. Memoirs of the New York Botanical Garden 32: 21-305.

ANDERson, W. R. 1990a. The origin of the Malpighiaceae-the evidence from morphology. Memoirs of the New York Botanical Garden 64: 210224.

ANDERSON, W. R. 1990b. The taxonomy of Jubelina (Malpighiaceae). Contributions from the University of Michigan Herbarium 17: 21-37.

ANDERson, W. R. 1990c. Notes on neotropical Malpighiaceae-III. Contributions from the University of Michigan Herbarium 17: 39-54.

ANDERson, W. R. 1993. Chromosome numbers of neotropical Malpighiaceae. Contributions from the University of Michigan Herbarium 19: 341-354.

Anderson, W. R., AND B. Gates. 1981. Barnebya, a new genus of Malpighiaceae from Brazil. Brittonia 33: 275-284.

APG [Angiosperm Phylogeny Group]. 1998. An ordinal classification for the families of flowering plants. Annals of the Missouri Botanical Garden 85: 531-553.

ARMBruster, W. S. 1984. The role of resin in angiosperm pollination: ecological and chemical considerations. American Journal of Botany 71: $1149-1160$.

Cameron, K. M., M. W. Chase, W. M. Whitten, P. J. Kores, D. C. Jarrell, V. A. Albert, T. Yukawa, H. G. Hills, and D. H. Goldman. 1999. A phylogenetic analysis of the Orchidaceae: evidence from $r b c L$ nucleotide sequences. American Journal of Botany 86: 208-224.

Chase, M. W. 1981. A revision of Dicella (Malpighiaceae). Systematic Botany 6: 159-171.

Chase, M. W., AND H. G. Hills. 1991. Silica gel: an ideal material for field preservation of leaf samples for DNA studies. Taxon 40: 215-220.

Chase, M. W., C. M. Morton, And J. A. Kallunki. 1999. Phylogenetic relationships of Rutaceae: a cladistic analysis of the subfamilies using evidence from $r b c L$ and $a t p \mathrm{~B}$ sequence variation. American Journal of Botany 86: 1191-1199.

Chase, M. W., A. Y. De Bruijn, G. Reeves, A. V. Cox, P. J. Rudall, M. A. T. Johnson, and L. E. Eguiarte. 2000. Phylogenetics of Aspho- delaceae (Asparagales): an analysis of plastid $r b c L$ and $t r n L-F$ DNA sequences. Annals of Botany 86: 935-956.

Chase, M. W., ET AL. 1993. Phylogenetics of seed plants: an analysis of nucleotide sequences from the plastid gene rbcL. Annals of the Missouri Botanical Garden 80: 528-580.

CRePet, W. L. 1996. Timing in the evolution of derived floral characters: Upper Cretaceous (Turonian) taxa with tricolpate and tricolpate-derived pollen. Review of Palaeobotany and Palynology 90: 339-360.

CRepet, W. L., AND K. C. Nixon. 1998. Fossil Clusiaceae from the Late Cretaceous (Turonian) of New Jersey and implications regarding the history of bee pollination. American Journal of Botany 85: 1122-1133.

CRONQUist, A. 1981. An integrated system of classification of flowering plants. Columbia University Press, New York, New York, USA.

Davis, C. C., W. R. Anderson, And M. J. Donoghue. 2001. Phylogeny of Malpighiaceae: evidence from chloroplast $n d h F$ and $\operatorname{trnL}-F$ nucleotide sequences. American Journal of Botany 88: 1830-1846.

Dodson, C. 1962. The importance of pollination in the evolution of the orchids of tropical America. American Orchid Society Bulletin 31: 525554.

Doyle, J. J., AND J. S. Doyle. 1987. A rapid DNA isolation procedure for small quantities of fresh leaf tissue. Phytochemical Bulletin 19: 11-15.

FITCH, W. M. 1971. Toward defining the course of evolution: minimum change for a specific tree topology. Systematic Zoology 20: 406-416.

Gates, B. 1982. Banisteriopsis and Diplopterys (Malpighiaceae). Flora Neotropica 30.

Hutchinson, J. 1967. The genera of flowering plants, vol. 2. Oxford University Press, Oxford, UK.

Johnson, D. M. 1986. Revision of the neotropical genus Callaeum (Malpighiaceae). Systematic Botany 11: 335-353.

Johnson, L. A., AND D. E. SolTIS. 1994. matK sequences and phylogenetic reconstruction in Saxifragaceae s. str. Systematic Botany 19: 143-156.

Kores, P. J., P. H. Weston, M. Molvray, and M. W. Chase. 2000. Phylogenetic relationships within the Diurideae (Orchidaceae): inferences from plastid matK DNA sequences. In K. L. Wilson and D. A. Morrison [eds.], Monocots: systematics and evolution, 449-456. CSIRO, Collingwood, Victoria, Australia.

Lledó, M. D., M. B. Crespo, K. M. Cameron, M. F. Fay, and M. W. CHASE. 1998. Systematics of Plumbaginaceae based on cladistic analysis of $r b c L$ sequence data. Systematic Botany 23: 21-29.

Lobreau-CALLEN, D. 1983. Analyse de la répartition géographique des Malpighiaceae d'après les caractères du pollen et de la pollinisation. Bothalia 14: $871-881$.

LOwRIE, S. R. 1982. The palynology of the Malpighiaceae and its contribution to family systematics. Ph.D. dissertation, University Microfilms \#82-24999. University of Michigan, Ann Arbor, USA.

MADDISON, W., AND D. MADDISON, 1992. MacClade 3.04 software. Sinauer, Sunderland, Massachusetts, USA.

Morton, C. V. 1968. A typification of some subfamily, sectional, and subsectional names in the family Malpighiaceae. Taxon 17: 314-324.

NiedenZU, F. 1928. Malpighiaceae In A. Engler, Das Pflanzenreich IV, 141. W. Engelmann, Germany.

Olmstead, R., AND J. PAlmer. 1994. Chloroplast DNA systematics: a review of methods and data analysis. American Journal of Botany 81: $1205-1224$.

Olmstead, R., P. A. Reeves, And A. C. Yen. 1998. Patterns of sequence evolution and implications for parsimony analysis of chloroplast DNA. In D. E. Soltis, P. S. Soltis, and J. J. Doyle [eds.], Molecular systematics of plants, II, DNA sequencing, 164-187. Kluwer, Norwell, Massachusetts, USA.

Palmer, J., R. Jansen, H. Michaels, M. Chase, and J. Manhart. 1988. Chloroplast DNA variation and plant phylogeny. Annals of the Missouri Botanical Garden 75: 1180-1206.

PlunketT, G. M., D. E. Soltis, And P. S. Soltis. 1996. Evolutionary patterns in Apiaceae: inferences based on matK sequence data. Systematic Botany 21: 477-495.

Reeves, G., M. W. Chase, P. Goldblatt, T. De Chies, B. Lejeune, and P. J. RuDALL. In press. A phylogenetic analysis of Iridaceae based on four plastid sequences regions: trnL intron, $\operatorname{trn} L-F$ spacer, $r p s 4$ and $r b c L$. American Journal of Botany.

Savolainen, V., M. W. Chase, S. B. Hoot, C. M. Morton, D. E. Soltis, C. Bayer, M. F. Fay, A. Y. De Bruijn, S. Sullivan, and Y.-L. Qiu, 2000a. Phylogenetics of flowering plants based upon a combined anal- 
ysis of plastid $a t p B$ and $r b c L$ gene sequences. Systematic Biology 49: 306-362.

Savolainen, V., ET AL. 2000b. Phylogeny of the eudicots: a nearly complete familial analysis based on $r b c L$ gene sequences. Kew Bulletin 55: $257-$ 309.

Seelanan, T., A. Schnabel, and J. F. Wendel. 1997. Congruence and consensus in the cotton tribe (Malvaceae). Systematic Botany 22: 259290.

SOltis, D. E., ET AL. 2000. Angiosperm phylogeny inferred from $18 \mathrm{~S}$ rDNA, $r b c L$, and $a t p B$ sequences. Botanical Journal of the Linnean Society 133: 381-461.

Steele, K. P., And R. Vilgalys. 1994. Phylogenetic analysis of Polemoniaceae using nucleotide sequences of the plastid gene matK. Systematic Botany 19: 126-142.
SWOFFORD, D. L. 1999. PAUP*: phylogenetic analysis using parsimony, version $4.0 \mathrm{~b} 2$. Sinauer, Sunderland, Massachusetts, USA.

TAKHTAJAn, A. 1997. Diversity and classification of flowering plants. Columbia University Press, New York, New York, USA.

VogeL, S. 1990. History of the Malpighiaceae in the light of pollination ecology. Memoirs of the New York Botanical Garden 55: 130-142.

WIENS, J. J. 1998. Combining data sets with different phylogenetic histories. Systematic Biology 47: 568-581.

WhitTen, W. M., N. H. Williams, and M. W. Chase. 2000. Subtribal and generic relationships of Maxillarieae (Orchidaceae) with emphasis on Stanhopeinae: combined molecular evidence. American Journal of Botany 87: 1842-1856.

Xiang, Q.-Y., D. E. Soltis, AND P. S. Soltis. 1998. Phylogenetic relationships of Cornaceae and close relatives inferred from matK and $r b c L$ sequences. American Journal of Botany 85: 285-297. 